\title{
Silver-Chitosan Nanocomposite Prepared With Aqueous Sodium-hydroxide and Aqueous Acetic Acid Solutions: Characteristics and Their Cytotoxic Effects
}

\section{Laya Ebrahimi}

Shiraz University

Saeid Hosseinzadeh ( $\square$ saeid_hosseinzadeh@yahoo.com )

Shiraz University https://orcid.org/0000-0001-7691-6435

Maryam Montaseri

Shiraz University

\section{Enayat Berizi}

Shiraz University of Medical Sciences

Mohammad Hashem Yousefi

Shiraz University

Jaafar Jalaei

Shiraz University

Mansour Rahsepar

Shiraz University

\section{Research Article}

Keywords: Nanoparticle, Cytotoxicity, Silver-chitosan nanocomposite, Sodium-hydroxide, Acetic acid

Posted Date: December 3rd, 2021

DOI: https://doi.org/10.21203/rs.3.rs-1127558/v1

License: (c) (1) This work is licensed under a Creative Commons Attribution 4.0 International License. Read Full License 


\section{Abstract}

In this study cytotoxic effects of silver-chitosan nanocomposites with aqueous sodium-hydroxide solution (SCNC-ASHS), and aqueous acetic acid solution (SCNC-AAAS) were evaluated, in vitro. The morphology of the synthesized nanoparticles were characterized by Fourier-Transform Infrared Spectroscopy (FTIR), and Scanning Electron Microscopy (SEM). Their cytotoxicity were then evaluated using 3-(4,5-dimethylthiazol-2-yl)-2,5-diphenyl-2H-tetrazolium bromide (MTT) in concentrations of 1.56 to $400 \mu \mathrm{g} / \mathrm{ml}$, and acridine orange/ethidium bromide (AO/EB) staining after $24 \mathrm{~h}$ and $48 \mathrm{~h}$. Results showed the cytotoxicity of $400 \mu \mathrm{g} / \mathrm{ml}$ of SCNC-ASHS on Vero and HT-29 cells of $80.57 \%$ and $84.37 \%$ after $24 \mathrm{~h}$, and $82.20 \%$ and $84.84 \%$ after $48 \mathrm{~h}$. While, the values for SCNC-AAAS on Vero and HT-29 cell-lines were respectively $80.63 \%$ and $87.64 \%$ after $24 \mathrm{~h}$, and $83.60 \%$ and $87.44 \%$ after $48 \mathrm{~h}$. The most toxicity on HT-29 cells was belonged to SCNC-AAAS with $\mathrm{IC}_{50}$ of $40.4 \mu \mathrm{g} / \mathrm{ml}$. In the staining procedure, cell viability for 25 $\mu \mathrm{g} / \mathrm{ml}$ concentration of SCNC-AAAS was $41.84 \%$ in HT-29 cell and, for $6.25 \mu \mathrm{g} / \mathrm{ml}$ of SCNC-AAAS was $37.51 \%$ in Vero cells. A considerable decrease in cell viability was observed. Types of nanoparticles, synthesis methods, and different cell lines play role in inducing cytotoxicity. Anti-cancer effect of the nanoparticles on the colon cancerous cells (HT-29), of that SCNC-AAAS displayed higher effect than SCNC-ASHS.

\section{Introduction}

Chitosan, a deacetylated derivative of chitin, is considered as a food preservative due to its antimicrobial and antioxidant activities [1]. Its antimicrobial effect is due to the reaction between the positive charge of chitosan amino groups and the negative charge of microbial cell membranes, leading to the release of proteinases and other intracellular components of the microorganisms. The chitosan has been applied in nanotechnology for packaging and coating due to its ability to form films [2]. The use of nanotechnology in the food industry is dramatically increasing due to the new properties of materials at the nanometer scale [3]. Nanoparticles are made of natural or synthetic polymers in the size range below $100 \mathrm{~nm}$ [4]. Chitosan nanoparticles, produced from the natural polymer of chitosan, has displayed higher antimicrobial activity than the chitosan $[5,6]$. In addition, chitosan nanocomposites can be used in developing drug delivery vectors and nanocamposite based biosensors. For instance, chitosan nanocarriers can be developed by grafting chitosan to some hydrophobic amino acids and then employed as an appropriate drug delivery vector $[7,8]$. Metal nanoparticles are also widely used in modern food coatings. Silver nanoparticles have shown to have antimicrobial properties because they degrade sulfur and phosphorus compounds in proteins and the genetic material of bacteria. The chitosan can be used as a matrix to place silver nanoparticles in coatings, that is, chitosan-silver nanocomposites that have antimicrobial properties [9].

The toxicity of these nanoparticles, which used as antimicrobial agents in food coatings, should be investigated because of their migration to foods and consumption by people. Various size of the nanoparticles, different types of cell lines affect the cytotoxicity. Accordingly, some reports showed the cytotoxicity, and anti-cancer effects of silver-chitosan nanocomposite on human umbilical artery 
endothelial cells (HUAECs) and A549 cells (Lung cancer cell line), respectively [10, 11]. In contrast, some publications advocated the non-toxicity of the chitosan-coated silver nanoparticles on healthy dermis cells (ATCC CRL-2522TM), and macrophages $[9,12,13]$. Furthermore, limited information is reported about different kinds and concentrations of the nanoparticles.

With respect to the various type of nanoparticles, and the different types of cell lines, as well as limited information about the toxicity of the different types of nanoparticles and the nanoparticle concentrations, our study aimed to synthesize and investigate the toxicity of chitosan nanoparticles, and silver-chitosan nanocomposites, used in food coatings. Two synthesis methods of silver-chitosan nanocomposites were conducted including aqueous acetic acid (SCNC-AAAS) and sodium hydroxide solutions (SCNC-ASHS) and the properties of the synthesized nanoparticles were investigated using various methods such as FTIR and SEM. So far, the cytotoxic effect of these nanoparticles were not assayed on Vero cells (the epithelial cell class of African green monkeys) as normal cells, and HT-29 cells (colon cancer cells), simultaneously.

\section{Materials And Methods}

\subsection{Preparation of silver-chitosan nanocomposite (SCNC) 2.1.1. Preparation of SCNC with aqueous acetic acid solution (SCNC-AAAS)}

SCNC-AAAS was synthesized according to the method of Honary et al. with the following modifications [14]. At first, $100 \mathrm{ml}$ of chitosan solution $(0.5 \mathrm{mg} / \mathrm{ml})$ (Aldrich Chemical, Germany) was prepared in acetic acid solution (1-2\%) (Merck, Germany). Due to the poor solubility, chitosan was kept at room temperature for 24 hours. Second, the prepared solution was added to 1 liter of $6 \mathrm{mM}$ silver nitrate solution and was stirred for one hour on a stirrer (IKA, Germany). Third, the $58 \mathrm{mM}$ sodium borohydride $\left(\mathrm{NaBH}_{4}\right)$ solution (Merck, Germany) was then added dropwise until the color shift from colorless to brown. Finally, the solution was heated at $50^{\circ} \mathrm{C}$ by an oven (model CE.FH.151.4, Germany) to evaporate large amounts of water. The remained water was then completely removed by a freeze dryer (CHRIST, Germany).

\subsubsection{Preparation of SCNC with aqueous sodium hydroxide solution (SCNC-ASHS)}

SCNC-ASHS solution was synthesized according to the method of Akmaz et al., as follows [15]. $100 \mathrm{mg}$ of chitosan (Aldrich Chemical Company, Germany) was added to $50 \mathrm{ml}$ of $95^{\circ} \mathrm{C}$ water. While the suspension was sonicating (Iranian Knowledge-Based Company of Nasir Research, Iran), $1 \mathrm{ml}$ of $0.02 \mathrm{M}$ solution of silver nitrate $\left(\mathrm{AgNO}_{3}\right)$ (Merck, Germany) was added. Then, $100 \mu \mathrm{l}$ of $0.3 \mathrm{M}$ Sodium hydroxide $(\mathrm{NaOH})$ solution (Merck, Germany) was added dropwise. At this stage, the color changed from colorless to reddish-yellow. The solution was sonicated for 95 minutes at $95^{\circ} \mathrm{C}$. The nanoparticles were then washed with distilled water and dried by an oven (Memmert, Germany) at $50^{\circ} \mathrm{C}$. 


\subsection{Examination of nanoparticle characteristic \\ 2.2.1. Fourier-Transform Infrared Spectroscopy (FTIR)}

FTIR method was used to determine the molecules and biological functional groups responsible for nanoparticle synthesis (NIRS XDS, Metrohm, Swiss) [16].

\subsubsection{Scanning Electron Microscope (SEM)}

Images were taken by SEM. Image details such as magnification and voltage were recorded in the related image (TESCAN, Czech Republic, model-TESCAN-Vega 3)

\subsection{Cell culture}

Two cell lines HT-29 and Vero were considered for the experiment. In order to thaw the cells, they transferred into a falcon tube containing $10 \mathrm{ml}$ of RPMI 1640 complete culture medium containing GlutaMax (Shell Max, Iran) supplemented with 10\% fetal bovine serum (Gibco, USA), 1\% penicillinstreptomycin (100 IU/ml and $100 \mu \mathrm{g} / \mathrm{ml}$ ) (Bio-idea, Iran), and 0.05\% amphotericin B $(2.5 \mu \mathrm{g} / \mathrm{ml})$ (Sigma, USA). The cells were then centrifuged (Biosan, Latvia) at $1000 \mathrm{rpm}$ for 10 minutes and the supernatant was discarded. The sediment, containing cells, was then cultured in a T25 cell culture flask containing the complete culture medium and incubated at $37^{\circ} \mathrm{C}$ in the presence of $5 \% \mathrm{CO}_{2}$, and $95 \%$ humidity. The cell culture medium was changed every 48 hours to achieve about $90 \%$ confluency [17]. The cells were then detached with $300 \mu \mathrm{l}$ of $0.05 \%$ trypsin-versene solution (Bio-Idea Company, Iran) and were collected after the centrifugation (1000 rpm, 10 minutes) for the further cell treatment.

\subsection{Cytotoxicity test}

3-(4,5-dimethylthiazol-2-yl)-2,5-diphenyl-2H-tetrazolium bromide (MTT) test (Bio idea-Iran) was used to evaluate cell toxicity. Initially, $100 \mu \mathrm{l}$ of culture medium containing $10^{4}$ cells) was added to each well of 96-well microplate to reach the appropriate cell confluency. The cells were then treated with SCNC-AAAS, and SCNC-ASHS, and the cytotoxicity was fulfilled after $24 \mathrm{~h}$ and $48 \mathrm{~h}$ incubations. Both SCNCs were used at the concentrations of $400 \mu \mathrm{g} / \mathrm{ml}$ to $1.56 \mu \mathrm{g} / \mathrm{ml}$ with series of 2 -fold dilutions. Afterwards, the wells were evacuated and washed three times with phosphate-buffered saline (PBS). Three wells were considered for each concentration and for the control group, receiving no treatment. MTT test was performed according to the instructions given by the manufacturer. Accordingly, $100 \mu \mathrm{l}$ of RPMI-1640 without phenol red and $10 \mu \mathrm{l}$ of MTT $(12 \mathrm{mM})$ were added into the 96-well plate containing cells and placed in a $37^{\circ} \mathrm{C}$ incubator for $4 \mathrm{~h}$. Then, the contents of the wells were removed and $50 \mu \mathrm{l}$ of DMSO was added to the each well and incubated for 10 minutes at $37^{\circ} \mathrm{C}$. Finally, the microplate was measured at optical density (OD) value of $570 \mathrm{~nm}$ using a plate reader (BioTek, USA). This test was repeated three times, and the cytotoxicity percentage was calculated using the following equation $[18,19]$ :

$$
\mid \% \text { Cytotoxicity }=\left(1-\frac{\text { ODofthetestsample }}{\text { ODofthecontrol }}\right) \times 100
$$




\subsection{Acridine orange/ethidium bromide (AO/EB) fluorescent staining}

To evaluate cell apoptosis induced by SCNC-AAAS, AO/EB fluorescent staining was applied in both HT-29 and Vero cells. Firstly, $2 \times 10^{5}$ cells/well were seeded into 12-well tissue culture plates. After $72 \mathrm{~h}$ incubation, the supernatant was discarded and the monolayer cells were washed with PBS and supplemented with $6.25 \mu \mathrm{g} / \mathrm{ml}, 12.5 \mu \mathrm{g} / \mathrm{ml}$, and $25 \mu \mathrm{g} / \mathrm{ml} \mathrm{SCNC-AAAS} \mathrm{for} \mathrm{HT-29} \mathrm{cell} \mathrm{line,} \mathrm{and} 1.56 \mu \mathrm{g} / \mathrm{ml}$, $3.12 \mu \mathrm{g} / \mathrm{ml}$, and $6.25 \mu \mathrm{g} / \mathrm{ml}$ SCNC-AAAS for Vero cells. Negative controls, without any treatment, were considered for both cell lines. The cells were incubated for $24 \mathrm{~h}\left(37^{\circ} \mathrm{C}, 5 \% \mathrm{CO}_{2}\right)$, and then were harvested

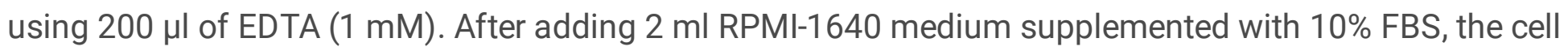
were centrifuged, and $200 \mu \mathrm{l}$ medium was added to the remained cells. $20 \mu \mathrm{l}$ of the cell suspension was mixed with an ethidium bromide/acridine orange dye. Then, $10 \mu \mathrm{l}$ of the dyed cell was transferred to hemocytometer slide and assessed using fluorescence microscope (CETI, 040856, Belgium) at $\times 20$ magnification $[20,21]$.

\subsection{Preparation of cells for microscopy \\ 2.6.1. Preparation of cells for the phase-contrast microscopy}

About $1.5 \times 10^{5}$ cells (HT-29 or Vero cells), suspended in $2 \mathrm{ml}$ of RPMI- 1640 medium, were seeded into a six-well plate and incubated $\left(37^{\circ} \mathrm{C}, 5 \% \mathrm{CO}_{2}\right)$. After the cell monolayer formation, $400 \mu \mathrm{g} / \mathrm{ml}$ of each SCNCs-AAAS and SCNCs-ASHS were added into both HT-29 and Vero cell lines and the plates were incubated $\left(37^{\circ} \mathrm{C}, 5 \% \mathrm{CO}_{2}\right)$ for $24 \mathrm{~h}$. The cells were examined by phase-contrast microscopy (Optika, Italy) at $\times 10$ magnification, morphologically [22].

\subsubsection{Preparation of cells for the scanning electron microscopy (SEM)}

Initially, about $1.5 \times 10^{5}$ cells (HT-29 or Vero cells) were cultured in six-well plates and incubated. After formation of the cell monolayers, the cells were evaluated by adding different concentrations of SCNCAAAS or SCNC-ASHS into the wells and were incubated for 24 hours. SCNC-AAAS concentrations were considered $100 \mu \mathrm{g} / \mathrm{ml}$ in Vero cells and $12.5 \mu \mathrm{g} / \mathrm{ml}$ in HT-29 cells, while SCNC-ASHS was added at a concentration of $100 \mu \mathrm{g} / \mathrm{ml}$ and $6.25 \mu \mathrm{g} / \mathrm{ml}$ in HT-29 cells and Vero cells, respectively.. The cells were then washed with PBS, and fixed with $3 \%$ glutaraldehyde (Dae Jung, Korea) for 2 hours at $4^{\circ} \mathrm{C}$. To dehydrate the cells, alcohol (Merck, Germany) with concentrations of $50 \%, 60 \%, 70 \%, 80 \%, 90 \%$, and $100 \%$ were exerted for 30 minutes for each concentration; the plate was finally kept in a laminar flow hood for 2 hours at room temperature. The cell images were then taken by electron microscopy [23, 24].

\subsection{Statistical analysis}


All data were analyzed as mean \pm standard deviation (SD) in triplicate experiment. Statistical significance for MTT test was determined by one-way analysis of variance and independent t-test using SPSS v.19 software. $\mathrm{P}<0.05$ was considered statistically significant. $\mathrm{IC}_{50}$ was calculated using non-linear regression analysis method in GraphPad Prism v.8.3.0 software.

\section{Results}

\subsection{SCNCs Microscopy \\ 3.1.1. FTIR spectroscopy}

Fourier transform infrared spectroscopy analysis was carried out to identify the chemical structures of SCNC-AAAS and SCNC-ASHS. Details are given in Figure 1. The spectral shifts of the diagram in the 3350 $\mathrm{cm}^{-1}$ frequency shows the presence of amine and hydroxyl groups and their overlap, also the shifts occurred in the $2880 \mathrm{~cm}^{-1}$ wavenumber resulted from the presence of $\mathrm{CH}_{2}$ in chitosan and nanocomposite. The peak observed at $1513 \mathrm{~cm}^{-1}$ indicates the bending vibration of the $\mathrm{NH}$ band. It is noticeable that the interaction of $\mathrm{NH}_{2}$ or $\mathrm{O}-\mathrm{H}$ groups of chitosan with silver ions tends their vibrations peak to lower wavenumbers. The sharp peak observed in $1284 \mathrm{~cm}^{-1}$ wavenumber represents the $\mathrm{CH}_{2}$ wagging vibrations. The changes in the frequency range from 1060 to $1020 \mathrm{~cm}^{-1}$ are usually corresponded to $\mathrm{C}-\mathrm{N}$ and $\mathrm{C}-\mathrm{O}$ stretching vibrations in which the $\mathrm{C}-\mathrm{O}$ stretching vibrations is formed in the frequency of the composite combined with. The relatively sharp peak detected in the frequency of 800 $\mathrm{cm}^{-1}$ indicates the absorption of $\mathrm{NO}_{3}{ }^{-}$ions from silver nitrate salt. The peak observed in $670 \mathrm{~cm}^{-1}$ can be the result of reducing activity of chitosan and metallic silver precipitation. Seemingly, the saccharide structure undergo changes after adsorption of silver ions detectable at $1050 \mathrm{~cm}^{-1}$ peak [25-27]

\subsubsection{Scanning Electron Microscopy}

The size and morphology of the nanocomposites which recorded by SEM have been shown in Figure 2 . SCNC-AAAS are detectable with cubic shapes and with the both sizes of smaller and larger than $100 \mathrm{~nm}$; while, SCNC-ASAH are spherical-shape with the size of smaller than $100 \mathrm{~nm}$.

\subsection{Cytotoxicity}

The cytotoxicity effects of SCNC-ASAH (from 400 to $1.56 \mu \mathrm{g} / \mathrm{ml}$ ) on HT-29 and Vero cells are shown in Figure 3. The cytotoxicity of SCNC-ASAH on HT-29 and Vero cells was significantly increased between the time $24 \mathrm{~h}$ and $48 \mathrm{~h}$, and the nanoparticle concentrations $(p<0.05)$

\subsection{1. $\mathrm{IC}_{50}$ value of SCNCs in HT-29 and Vero cell lines}


The $\mathrm{IC}_{50}$ values of SCNC-AAAS in HT-29 and Vero cells were determined as 4.4 and $13.40 \mu \mathrm{g} / \mathrm{ml}$, respectively. Since HT-29 cell line showed a lower $\mathrm{IC}_{50}$ value, its sensitivity to SCNC-AAAS was higher than that of Vero cells. Furthermore, $I_{50}$ values of SCNC-ASHS in HT-29 and Vero cells were calculated 11.54 and $19.36 \mu \mathrm{g} / \mathrm{ml}$, respectively. Lower IC $_{50}$ value of HT-29 cells implied higher cell sensitivity to SCNCASHS than that of Vero cells.

\subsection{Acridine orange/ethidium bromide (AO/EB) fluorescent staining}

The cell viability, early apoptosis, late apoptosis, and necrosis were examined in the presences of SCNCAAAS and SCNC-ASHS by AO/EB staining (Fig. 4). The results showed that when SCNCs concentrations increased, cell viability rates decreased, and early apoptosis, late apoptosis, and necrosis increased.

\subsection{Cell microscopy treated with different concentrations of SCNCs}

\subsubsection{Phase-contrast microscopy}

Changes in morphology of both HT-29 and Vero cells after 24 hours of treatment with SCNC-AAAS and SCNC-ASHS nanoparticles were recorded by contrast phase microscopy. The changes such as decrease in cell adhesion and increase in floating cells were observed.

\subsubsection{Scanning Electron Microscopy}

The cell morphology changes after 24h of treatment are illustrated in Figure 5. The control group, which did not receive any treatments, showed a normal shape and surface, while the treated cells were changed to the honeycomb structure, holes appeared in the cell membrane. Cell death resulted from leakage of intracellular contents throughout the cell membrane.

\section{Discussion}

The antimicrobial properties of chitosan have been enhanced by loading chitosan with various metals. Among all antimicrobial metals, silver possesses great toxicity against a wide range of microorganisms. Nanocomposites based on silver nanoparticles (SNPs) have been used as antimicrobial films for food packaging [26]. However, the toxicology of SNPs has still remained unknown. Additionally, SNPs can be absorbed into the bloodstream via different routes of administration, leading to deposition of silver in many organs, including the liver and spleen, and potentially can damage the organ. Previous researches have shown that different surface stabilizers have distinct impacts on SNPs cytotoxicity. Chitosan, because of its good biocompatibility and antibacterial properties, is often employed as the active ingredient of topical wound materials in combination with SNPs [28]. Chitosan is also used as a stabilizer instead of chemical reducing agents for protecting SNPs from agglomeration [15]. 
In the present study, chitosan was employed for producing SCNC in which sodium borohydride and sodium hydroxide were used as the reducing agent for silver ions to produce SCNC-AAAS and SCNCASHS, respectively. They revealed cytotoxic effects, dependent to the dose and time, on both HT-29 colon cancer cells and normal Vero cells.

Palem et al. reported a 5-7\% cytotoxicity on normal $3 T 3$ fibroblasts and cancer HeLa cells in the presence of SCNC [29]. Their results were in accordance with our findings. In the present study, a toxicity in both normal and cancer cells was observed in the presence of SCNC.

SCNC is reported to have anti-cancer effect on A549 lung cancer cells, with $\mathrm{IC}_{50}$ of $29.35 \mu \mathrm{g} / \mathrm{ml}$ [10]. This study also showed that SCNC-AAAS and SCNC-ASHS with $\mathrm{IC}_{50}$ of 4.40 and $11.54 \mu \mathrm{g} / \mathrm{ml}$ possessed anticancer effects on HT-29 cells, respectively. It is indicated that Ag-doped chitosan-poly vinyl alcohol nanocomposites impact more on human liver cancer (HEPG2) cells with $\mathrm{IC}_{50}$ of $43.7 \mu \mathrm{g} / \mathrm{ml}$ than breast cancer (MCF7) cells with $\mathrm{IC}_{50}$ of $52.5 \mu \mathrm{g} / \mathrm{ml}$ [30]. This result is in accordance with our findings.

Tyliszczak et al. stated that chitosan-based hydrogels modified with SNPs produced by sodium borohydride in concentrations of 25, 50, 75 and 100 (wt\%), showed no toxic effect on dermis cells BJ (CRL-2522TM) [9]. Wang et al. reported that silver immobilized in the sliver nanoparticle-doped chitosan composite films, shows a significant influence on the cell adhesion and subsequent proliferation of human umbilical vein endothelial cells [11]. Jena et al. reported that chitosan-coated silver nanoparticles, using chitosan as stabilizing and reducing agent, showed no significant cytotoxic or DNA damage on the macrophages at the bactericidal dose [13]. The less toxic effects of SCNC in former studies was likely due to the type of cells. It appears that the reason of non-toxicity of SCNC in the mentioned studies compared to present study is the difference in the type of investigated cells so that normal dermis cells, umbilical vein endothelial cells and macrophages exerted more resistance to SCNC compared normal kidney epithelial cells and they did not undergo cytotoxicity.

SCNC size is a considerable aspect of different results, which can be varied from the less than $10 \mathrm{~nm}$ to more than $100 \mathrm{~nm}$, in our study. It seems that larger size $(100 \mathrm{~nm})$ of SCNC causes more cell biological consequences in comparison with smaller particles $(10 \mathrm{~nm})[9,31]$

Another influential factor is type of synthesis procedure of SCNC. In the current study, chitosan was alternatively used as a silver ion reducing agent instead of sodium borohydride, used in previous studies. Jena et al. showed that the same-size particles above $100 \mathrm{~nm}$, were not toxic to the macrophage [13]. Because of the cytotoxicity of our nanoparticles on the normal cells, the application of them is not recommended in food coatings. Our synthetic nano-particles were highly toxic on the cancerous cells, thus they could be used in treating cancers.

\section{Conclusion}

Finally, in the present study, SCNC-AAAS and SCNC-ASHS showed more toxic effects on the cancerous cells than the normal cells. However, SCNC-AAAS showed higher toxic effect on both normal and cancer 
cell lines compared to SCNC-ASHS. The results implied that the synthesis procedure of SCNCs plays a notable role in the nanoparticles cytotoxicity. Because of high toxic effects on normal cell line, both types of SCNCs, are not recommended for the food industry. Nevertheless, due to their proper anti-cancer effects, found in cell culture assay, they may be applicable in the treatment of the colon cancer that requires more subsequent studies. Furthermore, according to the results, exposure time, the nanoparticles concentrations, procedure of nanoparticles synthesis, and the cell line types considerably affect the cytotoxicity.

\section{Declarations}

\section{Acknowledgements}

The authors gratefully acknowledge the Research Affair of Shiraz University.

\section{Disclosure statement}

The authors report there are no competing interests to declare.

\section{References}

1. M. Zarei, B.M. Pourmahdi, Z. Keshavarz, Iran. Vet. J. 11(3); 56-66 (2015) [Persian].

2. M. Sabaghi, Y. Maghsoudlou, M. Khomeiri, A.M. Ziaiifar, Postharvest Biol. Technol. 1;110;224-8 (2015)

3. K.B. Narayanan, N. Sakthivel, Adv. Colloid Interface Sci. 169(2):59-79 (2011)

4. W. Gao, J.C. Lai, S. Leung, Front. Physiol. 3:321. (2012)

5. M. Zarei, Z. Ramezani, S. Ein-Tavasoly, M. Chadorbaf, J. Food Process. Preserv. 39(6):2180-7 (2015)

6. L. Qi, Z. Xu, X. Jiang, C. Hu, X. Zou, Carbohydr. Res. 339(16):2693-700 (2014)

7. M. Motiei, S. Kashanian, A. Taherpour, Drug. Dev. Ind. Pharm. Jan 2;43(1):1-1 (2017)

8. Y. Jiang, J. Wu, Electrophoresis. 40(16-17):2084-97 (2019)

9. B. Tyliszczak, A. Drabczyk, S. Kudłacik-Kramarczyk, K. Bialik-Wąs, R. Kijkowska, A. Sobczak-Kupiec, Colloids Surf. B. 160:325-30 (2017)

10. N. Arjunan, H.L.J. Kumari, C.M. Singaravelu, R. Kandasamy, J. Kandasamy, Int. J. Biol. Macromol. 92:77-87 (2016)

11. X-h. Wang, Z. Wang, J, Zhang, H-x. Qi, J. Chen, M. Xu, Bioengineered. 7(5):283-90 (2016)

12. J.F. Hernández-Sierra, $O$, Galicia-Cruz, A. Salinas-Acosta, F. Ruíz, M. Pierdant-Pérez, A. Pozos-Guillén, J. Clin. Pediatr. Dent. 36(1):37-42 (2011)

13. P. Jena, S. Mohanty, R. Mallick, B. Jacob, A. Sonawane, Int. J. Nanomedicine 7:1805 (2012)

14. S. Honary, K. Ghajar, P. Khazaeli, P. Shalchian, Tropical Journal of Pharmaceutical Research. 10(1) (2011) 
15. S. Akmaz, E. Dilaver Adıgüzel, M. Yasar, O. Erguven, Adv. Mater. Sci. Eng. (2013)

16. S.A. Loutfy, H.M.A. El-Din, M.H. Elberry, N.G. Allam, M. Hasanin, A.M. Abdellah, Adv. Nat. Sci.Nanosci. Nanotechnol. 7(3):035008 (2016)

17. M. Gagnon, A.Z. Berner, N. Chervet, C. Chassard, C. Lacroix, J. Microbiol. Methods 94(3):274-9 (2013)

18. A. Kawarizadeh, M. Pourmontaseri, M. Farzaneh, S. Hosseinzadeh, M. Ghaemi, M. Tabatabaei et al., J. Appl. Microbiol. 131(1), 449-459 (2021)

19. M. Poormontaseri, S. Hosseinzadeh, S.S. Shekarforoush, T. Kalantari, BMC Microbiol. 17(1):1-8 (2017)

20. N. Hosseinzadeh, T. Shomali, S. Hosseinzadeh, F. Raouf Fard, M. Pourmontaseri, M. Fazeli. J. Pharm. Pharmacol. 72(8):1013-25 (2020)

21. A. Kawarizadeh, M. Pourmontaseri, M. Farzaneh, S. Hossinzadeh, Z. Pourmontaseri, Microb. Pathog. 150:104685 (2021)

22. Y-H. Lee, F-Y. Cheng, H-W. Chiu, J-C. Tsai, C-Y, Fang, C-W. Chen et al., 35(16):4706-15 (2014)

23. A. Saudi, M. Rafienia, A. Zargar Kharazi, H. Salehi, A. Zarrabi, M. Karevan, Polym. Adv. Technol. 30(6):1427-40 (2019)

24. D. Viet Quang, N. Hoai Chau, J. Powder Technol. Nov 4;2013 (2013)

25. J. An, Q. Luo, X. Yuan, D. Wang, X. Li, J. Appl. Polym. Sci. Jun 15;120(6):3180-9 (2011)

26. P. Kaur, A. Choudhary, R. Thakur, Int. J. Sci. Eng. Res. 4(4):869 (2013)

27. S. Kumar-Krishnan, E. Prokhorov, M. Hernández-Iturriaga, J.D. Mota-Morales, M. Vázquez-Lepe, Y. Kovalenko et al., Eur. Polym. J. 67:242-51 (2015)

28. Y. Peng, C. Song, C. Yang, Q. Guo, M. Yao, Int. J. Nanomedicine. 12:295 (2017)

29. R.R. Palem, N. Saha, G.D. Shimoga, Z. Kronekova, M. Sláviková, P. Saha, Int. J. Polym. Mater. 67(1):1$10(2018)$

30. A. Abaza, G. Mahmoud, E. Hegazy, M. Amin, E. Shoukry, B. Elsheikh, J. Pharm. (2018)

31. T.G. Souza, V.S. Ciminelli, N.D.S. Mohallem, J. Phys. Conf .Ser. IOP Publishing (2016)

\section{Figures}

\section{Figure 1}

Fourier transform infrared (FTIR) spectroscopy analysis to identify the chemical structures of SCNC-AAAS and SCNC-ASHS. (a) The characterized peak of silver chitosan nanocomposite with aqueous acetic acid solution (SCNCs-AAAS), (b) the characterized peak of silver chitosan nanocomposite with aqueous sodium hydroxide solution (SCNCs-ASHS). 

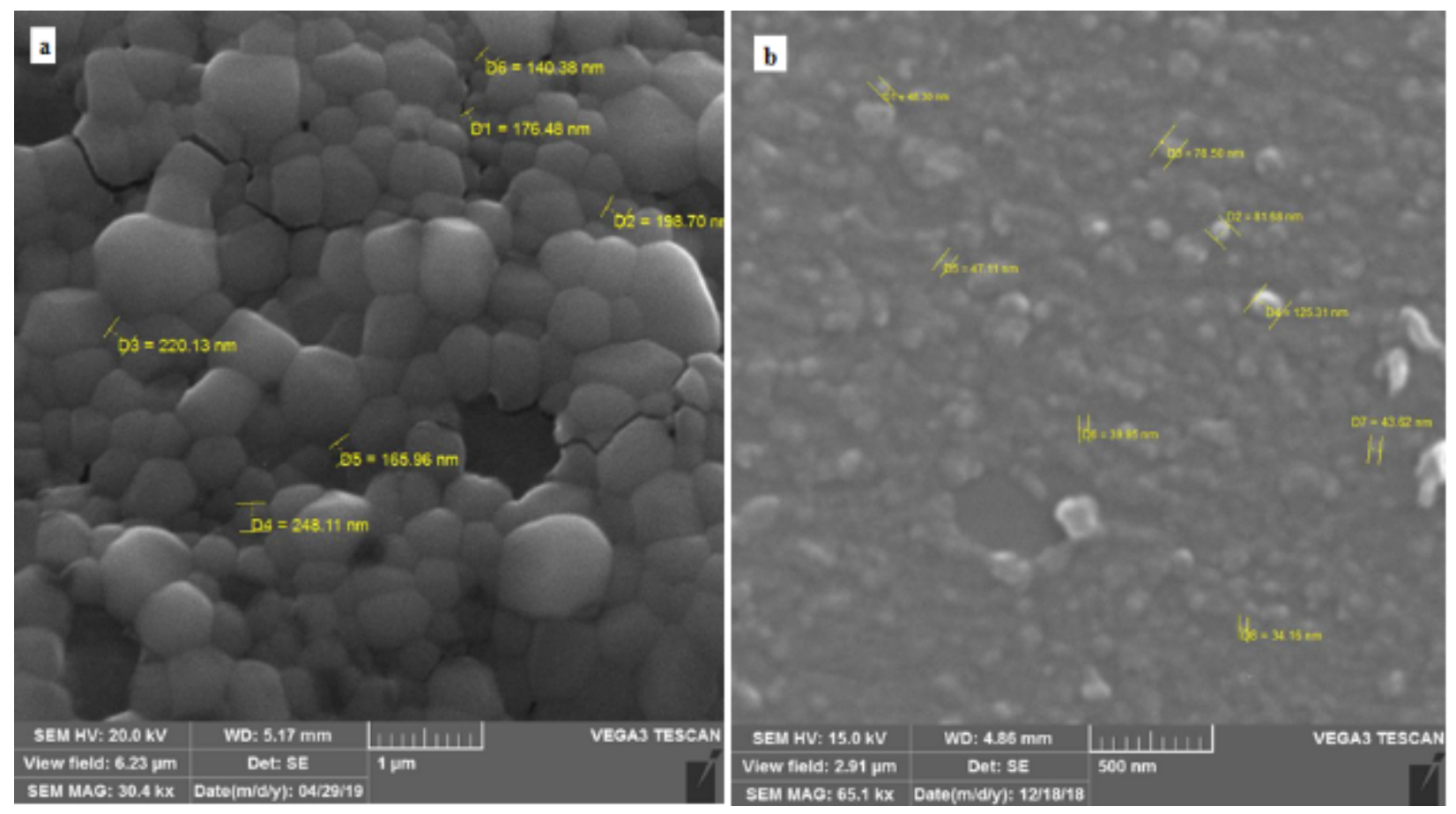

\section{Figure 2}

Scanning Electron Microscopy (SEM) images to characterize the size and morphology of the nanocomposites. (a) Silver chitosan nanocomposite with aqueous acetic acid solution (SCNCs-AAAS) are cubic shapes and the sizes of smaller and larger than $100 \mathrm{~nm}$, and (b) silver chitosan nanocomposite with aqueous sodium-hydroxide (SCNCs-ASHS) solution are spherical-shape and smaller than $100 \mathrm{~nm}$. 


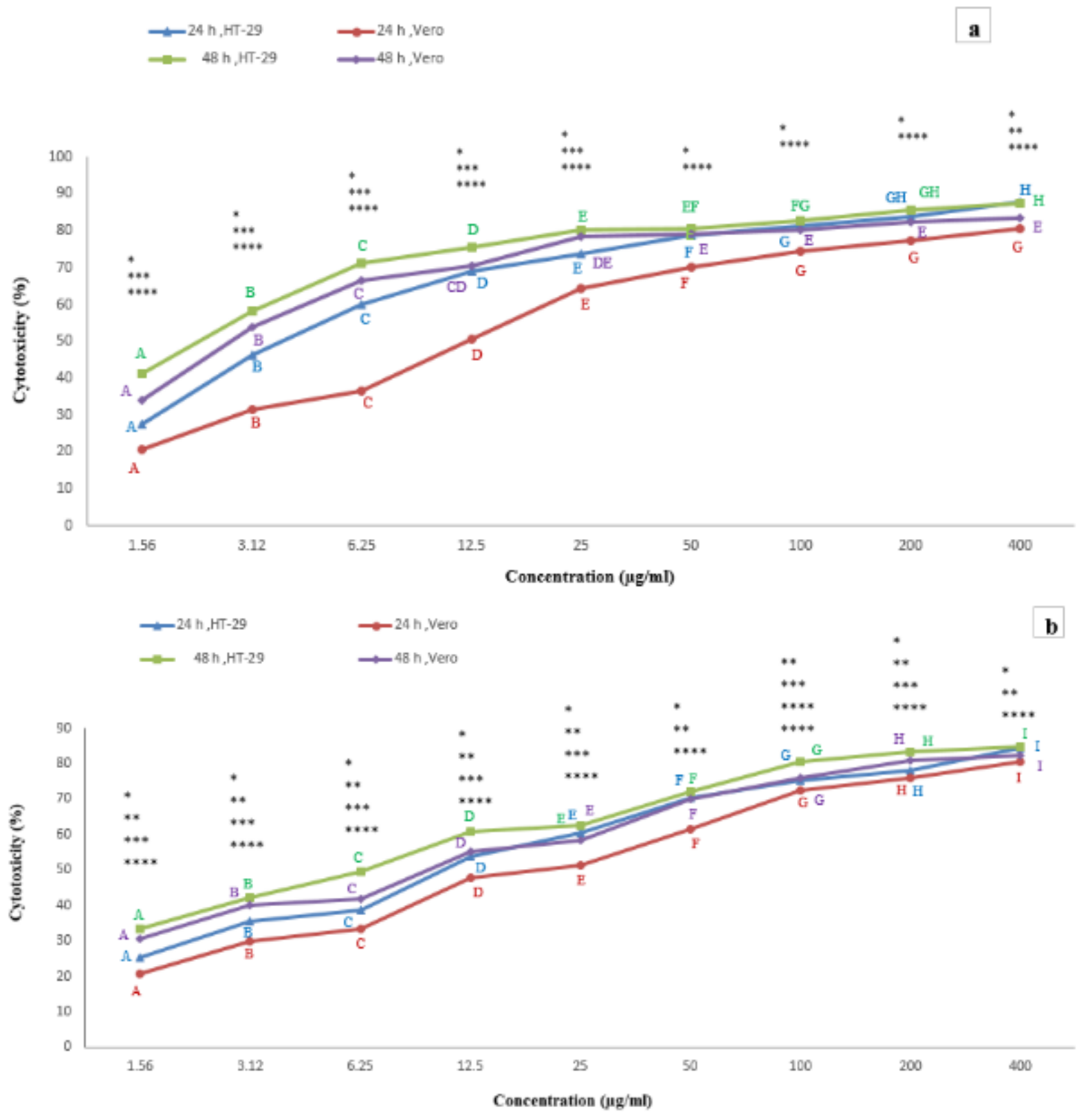

Figure 3

The cytotoxic effects of the nanocomposites on HT-29 and Vero cells. (a) Various concentrations (1.56 $\mu \mathrm{g} / \mathrm{ml}$ to $400 \mu \mathrm{g} / \mathrm{ml}$ ) of silver chitosan nanocomposite with aqueous acetic acid solution (SCNC-AAAS), and (b) silver chitosan nanocomposite with aqueous sodium-hydroxide solution (SCNC-ASHS) after $24 \mathrm{~h}$ and $48 \mathrm{~h}$. Similar letters denote no statistically significant difference between different concentrations. The sign * represents a significant difference in 24 hours between HT-29 and Vero cells, the sign **

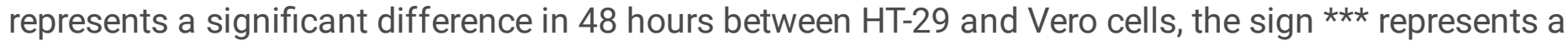

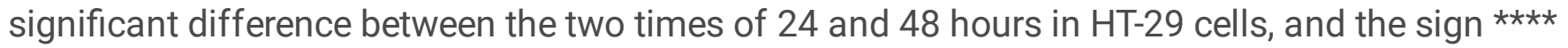
represents a significant difference between the two times of 24 and 48 hours in the Vero cell $(p<0.05)$. 
Viability, early apoptosis, late apoptosis, and necrosis of HT-29 cells (a) and Vero cells (b) in the presence of various concentrations of silver chitosan nanocomposite with aqueous acetic acid solution (SCNCAAAS) after $72 \mathrm{~h}$ using acridine orange/ethidium bromide (AO/EB) fluorescent staining. Similar letters denote no statistically significant difference between different concentrations $(p>0.05)$
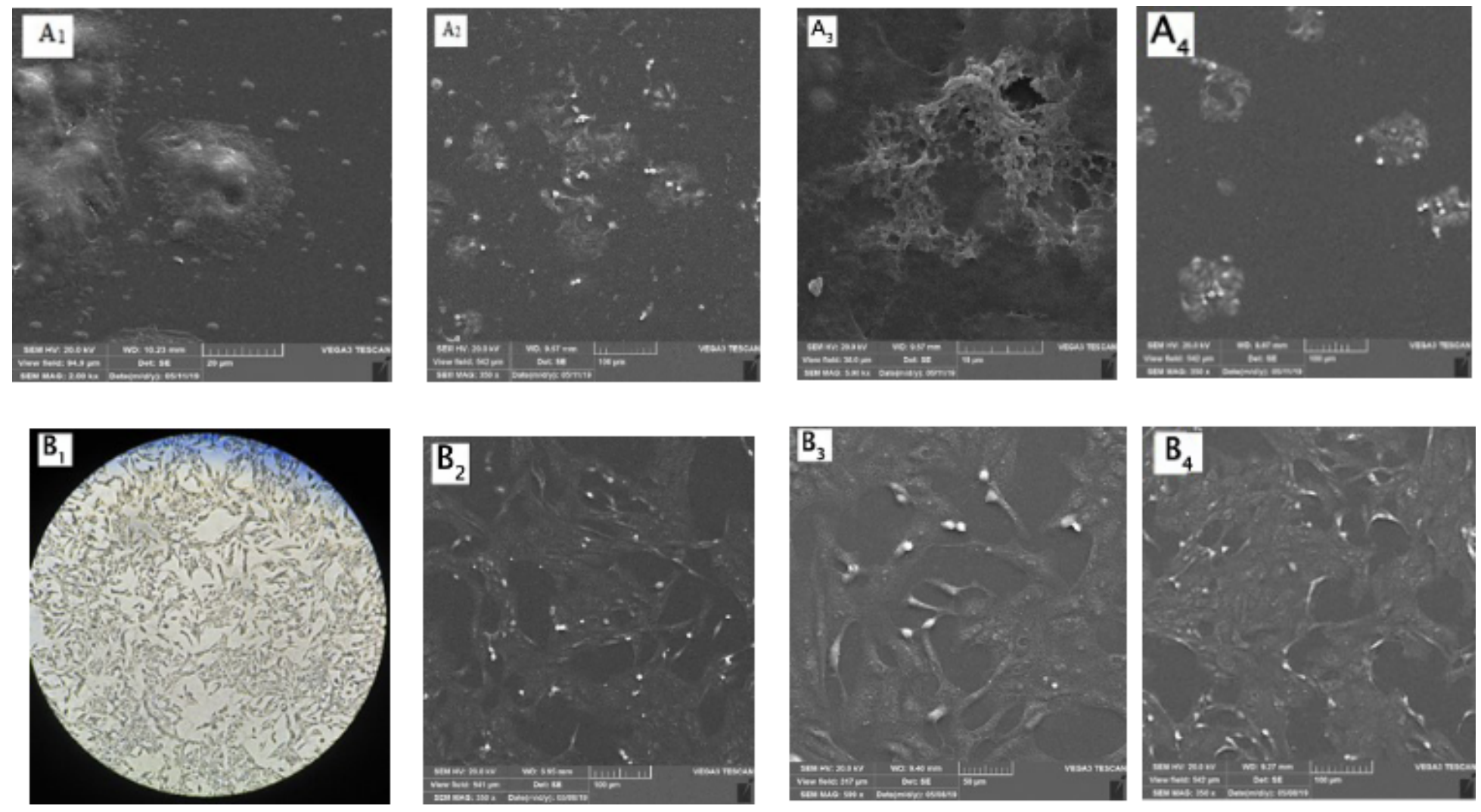

\section{Figure 5}

Effects of silver chitosan nanocomposite with aqueous acetic acid solution (SCNCs-AAAS) (A2, B2), and silver chitosan nanocomposite with aqueous sodium-hydroxide solution (SCNCs-ASHS) (A3, B3) on morphology of Vero and HT-29 cells. A: HT-29 cell line, and B: Vero cell line. A1: control group (concentration of $0 \mu \mathrm{g} / \mathrm{ml}$ ), A2, A3 and A4: concentration of $400 \mu \mathrm{g} / \mathrm{ml}$; and B1: the fixed cells shown by contrast phase microscope at 10x magnification before scanning electron microscopy image, B2: control group (concentration of $0 \mu \mathrm{g} / \mathrm{ml}$ ), B3: concentration of $12.5 \mu \mathrm{g} / \mathrm{ml}$, and B4: concentration of $6.25 \mu \mathrm{g} / \mathrm{ml}$ 